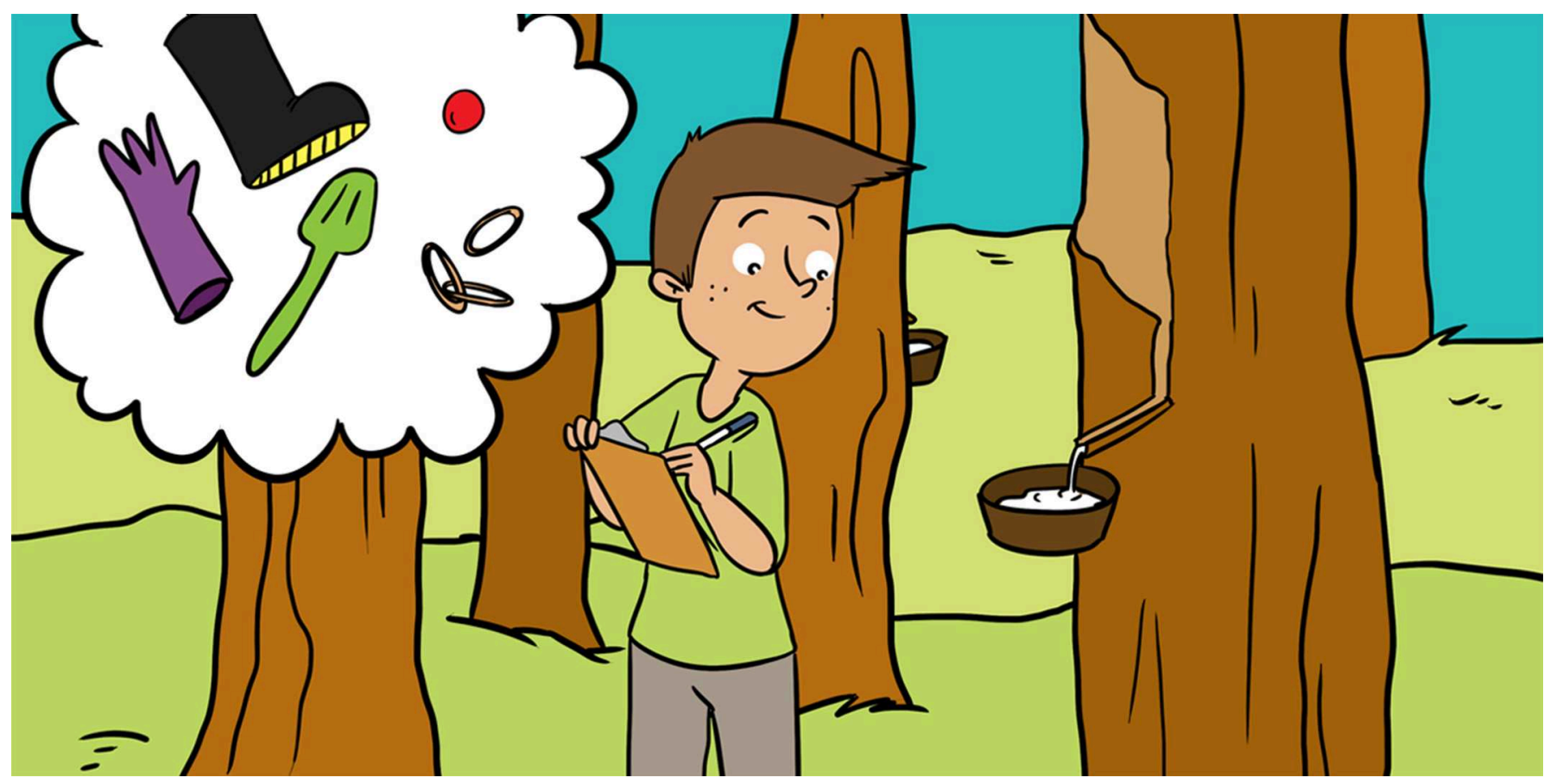

\title{
WHAT IS NATURAL RUBBER AND WHY ARE WE SEARCHING FOR NEW SOURCES?
}

\section{Marina Arias * and Peter J. van Dijk}

Vegetable Crop Research Unit, KeyGene, Wageningen, Netherlands

\section{YOUNG REVIEWERS:}

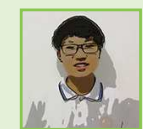

SIYAN

AGE: 14

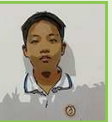

2 ZHUOCAN

AGE: 13

\section{POLYMER}

A chemical compound with large molecules made of many smaller molecules of the same kind. Some polymers exist naturally and others are produced in laboratories

and factories.
What is rubber and where does it come from? Rubber is a natural product produced by plants and is present in many of the goods used in our daily lives. Rubber has had an important role in human history, throughout the development of human civilizations. It still plays an important role, and that is why we need to search for new rubber sources. Nowadays, $99 \%$ of the natural rubber we use is extracted from a tree called Hevea brasiliensis. In this article, we give some details about the best alternative rubber sources currently available.

\section{WHAT IS NATURAL RUBBER?}

Natural rubber is produced from plants and is classified as a polymer. A polymer is a chemical compound with large molecules made of many smaller molecules of the same kind. Some polymers exist naturally and others are produced in laboratories and factories. 


\section{LATEX}

A whitish milky fluid containing proteins, starch, alkaloids, etc., that is produced by many plants. In some plants it also contains rubber.

\section{HEVEA}

\section{BRASILIENSIS}

It is a tree native to the Amazon. It is economically very important because the latex collected from the tree is the primary source of natural rubber.

Natural rubber is one of the most important polymers for human society. Natural rubber is an essential raw material used in the creation of more than 40,000 products. It is used in medical devices, surgical gloves, aircraft and car tires, pacifiers, clothes, toys, etc. Natural rubber is obtained from latex, a milky liquid present in either the latex vessels (ducts) or in the cells of rubber-producing plants. Around 20,000 species of plants produce latex, but only 2,500 species have been found to contain rubber in their latex. The biological function of rubber for the plants is not fully known. However, it has been shown that rubber can help plants to heal after they are damaged, by covering wounds and stopping the bleeding. This blocks the entry of harmful bacteria and viruses into the plants.

The properties of rubber include high strength and the capability to be stretched many times without breaking. Natural rubber compounds are exceptionally flexible, good electrical insulators, and are resistant to many corrosive substances [1].

Synthetic (man-made) rubber can be produced through a chemical process, but people have not been able to produce a synthetic rubber that has all the properties of natural rubber. So, natural rubber cannot be replaced by synthetic rubber in most of its applications. This is why natural rubber is still very important to human society [2].

\section{THE HISTORY OF NATURAL RUBBER}

As far back as 1600 B.C., Mesoamerican peoples in Mexico and Central America were using liquid rubber for medicines, in rituals, and to paint. It was not until the conquest of America that the use of rubber reached the western World. Christopher Columbus was responsible for finding rubber in the early 1490s. Natives from Haiti played football with a ball made of rubber, and later, in 1615, Fray Juan de Torquemada wrote about indigenous and Spanish settlers of South America wearing shoes, clothing and hats made by dipping cloth into latex, making these items stronger and waterproof. But rubber had some problems: it became sticky in response to warm weather and it hardened and cracked with cold weather.

One century later, in 1734, Charles Marie de la Condamine went to South America on a trip. There, he found two different trees containing latex: Hevea brasiliensis (Figure 1B) and Castilla elastica [3], but only the first became important as a natural rubber source. The reason why the Hevea tree succeeded over the Castilla tree was the way its latex was transported along the trunk. The Hevea tree has connected latex tubes (Figure 1A) that form a network, whereas the Castilla tree does not form a connected system. Thanks to its connected system, the Hevea tree bleeds latex when a special incision is made in its trunk (Figure 2). Without the latex tube connections, the Castilla tree does not bleed latex, making harvest of rubber more difficult. 
Figure 1

(A) Hevea brasiliensis trunk section and magnification of a longitudinal section of the connected tubes.

(B) A Hevea brasiliensis plantation and a drawing of the leaves, flowers, and fruit of this plant.

\section{Figure 2}

Hevea brasiliensis, with a special incision made for latex extraction.

\section{VULCANIZATION}

Process of treating rubber with sulfur and heat, to harden it while keeping its elasticity.
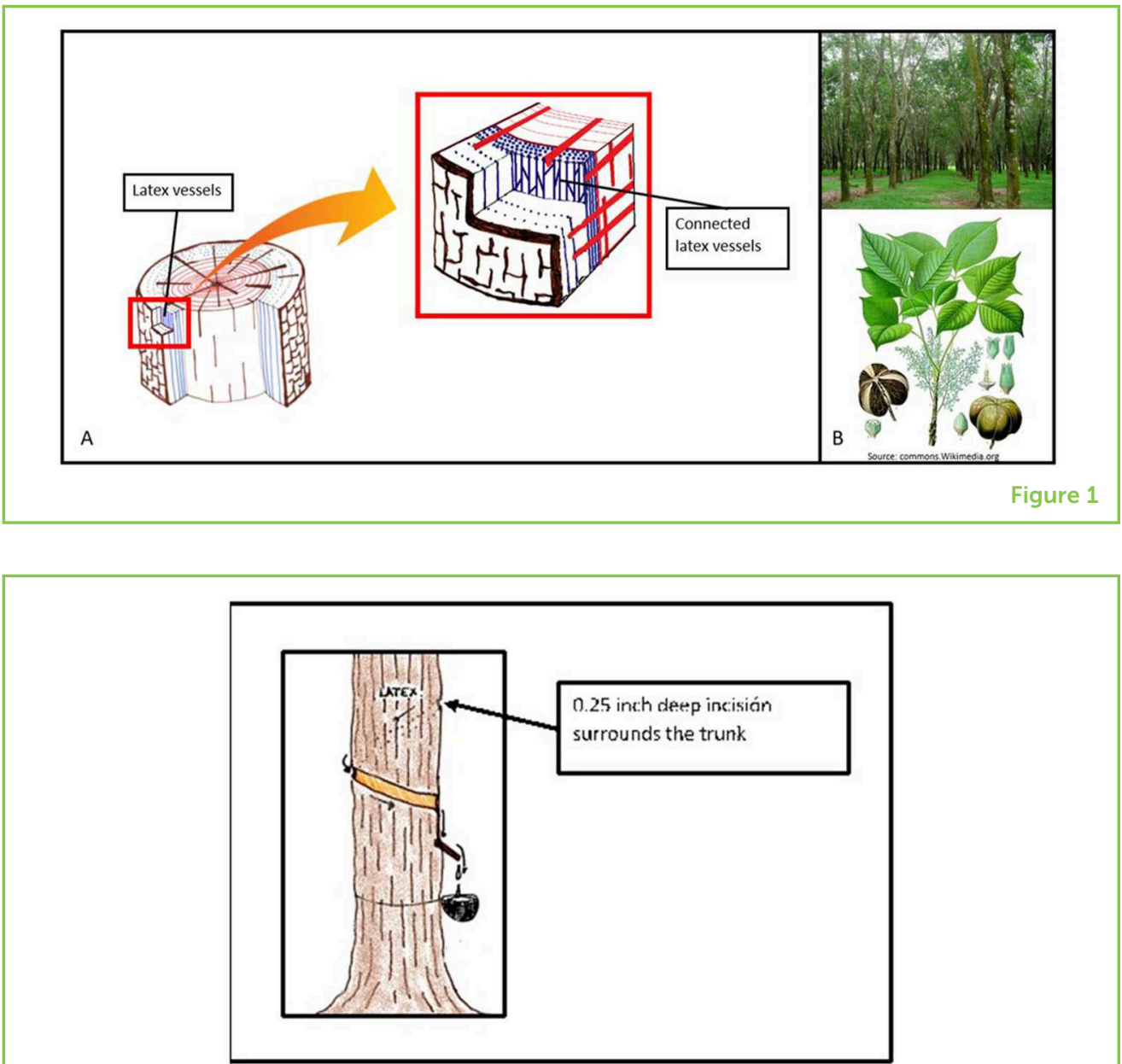

Figure 2

In 1839, Charles Goodyear invented the vulcanization process, solving many of the problems associated with rubber. Vulcanization is the process of treating rubber with sulfur and heat, to harden it while keeping its elasticity. It prevents rubber from melting in the summer and cracking in the winter. A few years after this important discovery, in 1888, Dunlop invented the air-filled rubber tire, making rubber an extremely important raw material worldwide. Rubber became an essential material for the Industrial Revolution.

From 1850 to 1920, businessmen were pushing entrepreneurs and traders to increase the amount of rubber extracted from Amazonian trees. During this period, the Brazilian Amazon was the only source of rubber and they controlled the price, making rubber expensive. At the same time, as more and more industry was developing in Europe and USA, more uses for rubber were being found [4]. Rubber was such an important material for Brazilians that they prohibited the export of rubber seeds or seedlings. However, in 1876, H. A. Wickham managed to smuggle 70,000 rubber seeds, hidden in banana leaves, and brought them to England. From those seeds, only 1,900 seedlings survived and were sent to Malaysia to start the first rubber plantations 
Figure 3

(A) Hevea brasiliensis originated in the Amazon and made its way to Malaysia, the main producer of natural rubber. (B) Hevea brasiliensis. (C) An alternative rubber source, guayule (Parthenium argentatum). (D) An alternative rubber source, Kazak dandelion (Taraxacum koksaghyz).

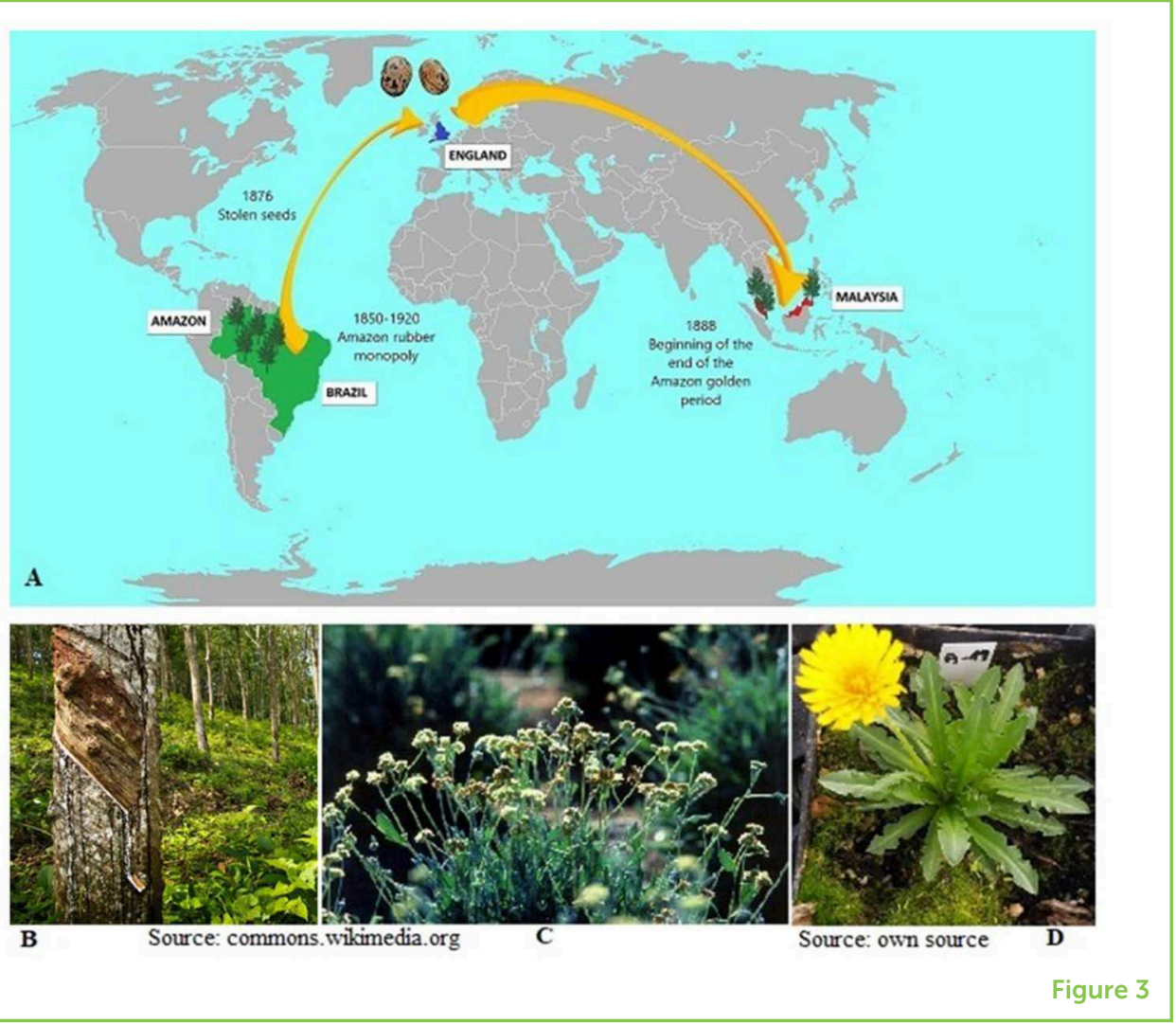

in Asia. This marked the beginning of the end for Brazil as the world's main rubber producer. After 12 years, rubber production in the new plantations in Malaysia were as competitive as the ones in the Amazon and these plantations soon became the world's main natural rubber supplier (Figure 3).

Henry Nicolas Ridley was a scientist who became director of the Singapore Botanic Gardens in 1888. While working there, he found the first 11 rubber trees that were planted in Malaysia and he started promoting the establishment of rubber tree plantations. Sometime later, he developed a revolutionary method for harvesting latex from the Hevea tree by continuous tapping. Tapping is the process of removing the latex from the tree. This discovery allowed a much higher latex yield to be achieved, and rubber became an essential material in Singapore's development. The new plantations were more competitive in price, so from the end of the nineteenth century until the First World War, rubber collection from wild sources in tropical America declined tremendously. During the war, the supply of rubber was cut off. The USA, Germany, and Russia started searching for alternative rubber sources, either natural or synthetic, since the Amazonian trees were not supplying enough rubber for their needs [3]. Several research programs started in these countries, but, after the war, the supply of rubber from Malaysian plantations started again and the effort to look for new rubber sources almost disappeared. 
Nowadays, around $90 \%$ of natural rubber is produced in Asia, with Thailand and Indonesia being the most important rubber suppliers (supplying more than $60 \%$ of the world's natural rubber).

\section{WHY ARE WE LOOKING FOR NEW RUBBER SOURCES?}

In recent years, the search for alternative sources of rubber has begun again. There are three main reasons for this:

\section{Threats to the Hevea brasiliensis tree and its rubber production}

First of all, the rubber trees are exposed to several diseases and since Asian rubber plantations started from only a handful of seeds, all the trees are genetically very similar. Less genetic variation means lower ability to fight against plant diseases. If one tree becomes sick, the illness can rapidly spread to the entire plantation. Today, the most important and dangerous disease that Hevea brasiliensis suffers from is called South American leaf blight disease. This disease can cause the devastation of an entire plantation. It is still confined to the tropical Americas, but if it arrives in Asia, it could mean the end of the rubber plantations. Under natural conditions, rubber trees commonly grow with a lot of space between them. In nature, serious damage to Hevea from South American leaf blight is unusual, because the other kinds of trees growing in between the rubber trees are not susceptible to the disease and act as barriers. But, on plantations where rubber trees grow very closely together, it can become lethal.

Second of all, an important threat to the natural rubber market is the very competitive and fast-growing market for palm oil and its side products. There is an increasing demand for both rubber and palm oil but, in Malaysia, the area in which Hevea brasiliensis is being grown is not decreasing, however, the area dedicated to grow oil palm is increasing. If the continuous growth of oil palm plantations does not stop, either the natural forest or the Hevea plantations will have to get smaller to make room for new crops of oil palms.

RUBBER TAPPING

Process of collecting latex from a rubber tree. A collecting groove is made in the bark of the tree before sunrise and the latex is collected in the late afternoon.
And last but not least, rubber tapping is a not well-paid job and it is difficult work. Young people tend to choose more attractive work, which could result in a shortage of skilled rubber tappers.

\section{Rubber from Hevea brasiliensis can cause serious allergy}

The latex proteins in rubber made from Hevea brasiliensis can produce severe allergies in certain people, even when they are exposed to very small amounts. The latex proteins are very difficult to separate from the rubber in the purification process. Since these allergies can be so 
dangerous, an alternative to rubber that does not contain these latex proteins would be advantageous.

\section{Hevea brasiliensis is only produced in a single area}

The conditions needed to grow these rubber trees are very specific and only occur in certain areas in the world. Most of our natural rubber is produced in a small region of Asia, making the supply vulnerable to damage. If the Asian plantations cannot produce enough rubber, rubber stocks could be insufficient for the world's needs. It would be helpful to be able to find other plants producing rubber that can be grown in other areas of the world.

\section{ARE THERE ANY ALTERNATIVE RUBBER SOURCES?}

Not all rubber-containing plants produce good-quality rubber. Some plants that have been considered as alternative rubber sources are guayule, Russian dandelion, rubber rabbit brush, goldenrod, sunflower, fig tree, and lettuce. Two of these plants seem to be the best alternatives to Hevea brasiliensis: guayule and Russian dandelion.

Guayule (Parthenium argentatum) is a native shrub of the north plateau region of Mexico, which usually grows in limestone soils in areas with very low rainfall (Figure $3 \mathrm{C}$ ). Guayule grows best when temperatures are between -18 and $49.5^{\circ} \mathrm{C}$. Under these conditions, it can live for $30-40$ years. Rubber is found in the stems and in the roots of guayule, and it is found in the individual cells of the plant, instead of in latex vessels or tubes. The rubber content of guayule increases over a period of several years. Less than $1 \%$ of the world's rubber comes from guayule. Rubber from this plant is studied for biomedical applications, because it does not cause allergies. In order to extract the rubber from the plant, guayule tissue must be thoroughly softened and smashed up to free the rubber particles contained in the individual cells. The quality of rubber from guayule is not good enough for all uses, because it has more impurities than does rubber from Hevea brasiliensis.

The other good option for rubber, Russian or Kazak dandelion (Taraxacum koksaghyz), is a fast-growing plant with a high-quality rubber that was discovered in 1931 in Kazakhstan (Figure 3D). Kazak dandelion grows very close to the ground, can be grown in regions with mild temperatures, and produces yellow flower heads (they look like a flower but they are a dense group of small flowers without stem). Kazak dandelion contains rubber in the leaves, flowers, and roots, but only rubber in the roots is good for extraction, due to its higher quality

RUBBER

EXTRACTION

The action of obtaining or separating rubber from the root tissue. and quantity. For rubber extraction, Russian dandelions must be either pressed or mixed [5]. Kazak dandelions have another advantage-they also produce a carbohydrate called inulin, which is a substance that can be used in foods as well as the production of medicines against 
cancer, biofuels, or even bioplastics (plastics made out of natural products). At this point, it is still too expensive to extract the rubber from Kazak dandelions. Through research, a plant with bigger root and higher rubber content can hopefully be developed.

\section{CONCLUSION}

Even though the rubber tree is the best source of rubber available today, it is facing some important threats. Rubber is only produced from plants that grown in certain unique areas. In order to expand the sources of natural rubber and avoid the dangers of limited production, we should search for new rubber-containing plants and improve the ones already known, to try to make them economically competitive.

\section{ACKNOWLEDGMENTS}

We would like to thank Natalia Carrero, Laura Barker, and Marcel Prins for their input in reviewing the text.

The AIR project has received funding from the European Union's Horizon 2020 research and innovation programme under the Marie Skłodowska-Curie grant agreement No. 752921.

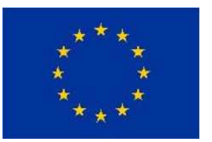

\section{REFERENCES}

1. Vijayaram, T. R. 2009. A technical review on rubber. Int. J. Des. Manuf. Tech. 3:25-36.

2. van Beilen, J., and Poirier, Y. 2007. Guayule and Russian dandelion as alternative sources of natural rubber. Crit. Rev. Biotech. 27:217-31. doi: 10.1080/07388550701775927

3. Whaley, W. G. 1948. Rubber-the primary source for American production. Econ. Bot. 2:198-216. doi: 10.1007/BF02859004

4. Ullán de la Rosa, F. J. 2004. La era del caucho en el Amazonas (1870-1920): modelos de explotación y relaciones sociales de producción. Anal. Mus. Am. 12:183-204.

5. van Beilen, J., and Poirier, Y. 2007. Establishment of new crops for the production of natural rubber. Trends Biotechnol. 25:522-9. doi: 10.1016/j.tibtech.2007.08.009

SUBMITTED: 25 January 2019; ACCEPTED: 05 July 2019; PUBLISHED ONLINE: 19 July 2019. 
EDITED BY: Anna Regoutz, University College London, United Kingdom

CITATION: Arias M and van Dijk PJ (2019) What is Natural Rubber and Why Are We Searching for New Sources? Front. Young Minds 7:100. doi: 10.3389/frym.2019. 00100

CONFLICT OF INTEREST STATEMENT: The authors declare that the research was conducted in the absence of any commercial or financial relationships that could be construed as a potential conflict of interest.

COPYRIGHT @ 2019 Arias and van Dijk. This is an open-access article distributed under the terms of the Creative Commons Attribution License (CC BY). The use, distribution or reproduction in other forums is permitted, provided the original author(s) and the copyright owner(s) are credited and that the original publication in this journal is cited, in accordance with accepted academic practice. No use, distribution or reproduction is permitted which does not comply with these terms.

\section{YOUNG REVIEWERS}

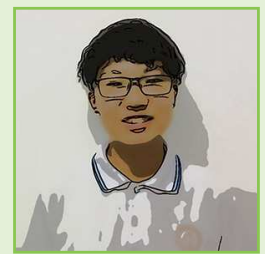

\section{SIYAN, AGE: 14}

I am a girl who loves speaking and laughing. I am good the subject of English. I have a lot of hobbies, such as playing the drums. I want to be a director when growing up, so I can make a lot of money. If I have money, I can do many interesting and meaningful things.

\section{YUSONG, AGE: 13}

I am a humorous boy. I love playing basketball and swimming. I am obsessed with delicious foods so I am a bit overweight. Math and Chinese are my favorite subjects. In my free time, I would like to play video games.

\section{ZHUOCAN, AGE: 13}

I am a smart boy from China. My favorite subjects are Math and Geography. And I like playing football and basketball.

\section{AUTHORS}

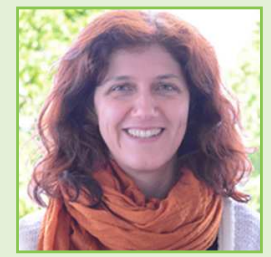

\section{MARINA ARIAS}

My name is Marina Arias Royo and I am from Spain, but I have been traveling and living in many different countries working with different research groups. I have a Ph.D. in Biology and I did some studies in marine biology, but I have mainly worked with plants. Nowadays I work as a postdoc in a company called KeyGene, in The Netherlands. I study how to get as much rubber as possible out of the rubber dandelion roots. And I grow them without soil, hydroponically!

*marina_arias@hotmail.com. 


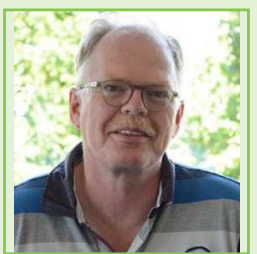

\section{PETER J. VAN DIJK}

I am Peter van Dijk and I am a biologist at KeyGene, a company in the Netherlands that improves plants by genetics. I have been studying dandelions for almost 25 years now. Besides in rubber I am very much interested in the way dandelions produce seeds. Dandelions are one of the very few plant species that can make sexless seeds, by a process called "apomixis." Apomictic seeds are exact genetic copies of the mother plant. I try to understand how dandelions do this, because introduction of apomixis could be very useful in crops. 